\title{
Trading Yahweh's Word for a Price: Ethical Implications of the Collusion of Prophets and Priests in Micah 3:5-7, $11^{1}$
}

\author{
Blessing Onoriode Boloje (University of Pretoria)
}

ABSTRACT

Trading Yahweh's word for a price is an attempt to articulate the implications of the mercenary attitude of prophets and priests in Micah 3:5-7, 11, in discharging their duties as religious functionaries. The article examines Micah's indictment of charismatic and cultic Judeans' self-centred leadership in commercialising Yahweh's word. This exploration is done against the background of the functions and responsibility of prophets and priests in the HB/OT. Prophets and priests both functioned in the religion of Ancient Israel and Judah as channels for the transmission of Yahweh's word to their people and nation. However, Micah presents a charismatic and cultic Judean leadership that was bereft of ethical standards of responsibility, reliability, constancy and integrity. Rather than embodying ethical character that could inspire confidence and commitment, they traded Yahweh's word for symbols of wealth and power and thus became stumbling blocks to genuine orthodoxy. Such attempts to lower the standard of God's demand on people so as to gratify oneself in a religious function that is designed to embody integrity, honesty, reliability and accountability constitute an affront to Yahweh. Additionally, it is an abuse of privilege and position, and amounts to religious deception and economic idolatry and creates a false sense of security.

KEYWORDS: Micah, prophets and priests, inverted oracles and commercialised teachings, Yahweh's word, wealth and power, economic idolatry.

* Submitted: 03/09/2018; peer-reviewed: 14/09/2018; accepted: 11/12/2018. Blessing Onoriode Boloje, "Trading Yahweh's Word for a Price: Ethical Implications of the Collusion of Prophets and Priests in Micah 3:5-7, 11," Old Testament Essays 31 no. 3 (2018): 630-650. DOI: https://doi.org/10.17159/2312-3621/2018/v31n3a13.

1 This article is an extensive revision of the paper presented at a Conference organised by the Department of Old Testament Studies, University of Pretoria from 31 August - 1 September 2017 on "Psalms, Prophets and (in) justice." It forms part of author's current research project on "The nexus between ethics and socio-economic actuality in Micah," at Ruhr-Universität Bochum, Germany. 


\section{A. INTRODUCTION}

Trading Yahweh's word for a price is an attempt to articulate the implications of the mercenary attitude of prophets and priests in Micah 3:5-7, 11 in discharging their duties as religious functionaries. There is no hesitation, whatsoever, that Micah's observation and indictments make sense today. Obviously, one lives in a world of material and economic consciousness where life is almost measured in terms of economics with unprecedented material prosperity contrasting with obvious abject material poverty, exploitation, corruption, and economic unrest. As it had been in Micah's time, religious leaders in faith communities today have resorted to the use of business strategies that are appealing to their advance of their ministerial functions. ${ }^{2}$ These religious merchants whose priority though not limited to financial gains - but may include increase in social status, recognition, reputation or other advantages - adopt distortions, deceptions and all manner of exaggerations to promote religious loyalty and increase popular appeal in their religious messages and doctrines. ${ }^{3}$

Micah indicts the religious functionaries (prophets and priests) for deceptively leading the people and perverting Yahweh's word for them. His indictment of deceptive leadership is amply strengthened with supportive evidence of selfishness driving their prophecies, divinations and teachings. They commercialised their ministries and placed materialistic and economic consciousness far above Yahweh's interests and the concerns of the people they were commissioned to serve. According to Micah, they announced and taught favourable and complimentary messages only and continuously to those who satisfied their greed with sufficient remuneration. Such attempts to lower the standard of God's demand on people so as to gratify themselves in a religious function designed to embody integrity, honesty, reliability and accountability constitute an abuse of privilege and position, religious deception, economic idolatry and affront to Yahweh.

In this article, in order to determine the implications of Micah's indictment of the charismatic and cultic Judeans' self-centred and self-serving

2 The description of faith communities in this article bears the stamp of my personal religious experience of Churches' life and Christian ministries in Africa especially in Nigeria where I have served as pastor and religious educator for over two decades. This relative description may also find similar expression in other nationalities across the globe.

3 Kenneth Baker, The NIV Study Bible (Grand Rapids: Zondervan Publishing House, 1995), 1899; Adrian Rogers, "False Prophets: Their Method, Manner and Motives," available@http://www.oneplace.com/ministries/love-worthfinding/read/ articles/false-prophets-theirmethod-manner-and-motive-14018.html (accessed 5th July 2018); Lon Hetrick, "Selling the Gospel: The Christian Hype that Stifles Christian Hope," available at http://felixcheakam.com/77-selling-Jesus-at-a-discount.html (accessed 5th July 2018). 
leadership a background of the functions and responsibility of prophets and priests in the HB/OT is presented. Prophets and priests both functioned in the religion of Ancient Israel and Judah as channels for the transmission of Yahweh's word to their people and nation. This functional background of prophets and priests is followed by an overview of the historical, socioeconomic, religious and cultural tensions in the book of Micah. Micah's indictments of Judean prophets and priests and the resulting implications of their unethical collusion constitute the final sections of the article.

\section{B. FUNCTIONS OF PROPHETS AND PRIESTS IN THE HEBREW BIBLE/OLD TESTAMENT}

One of the ways through which Ancient Israel and Judah uncovered and understood their relationship with Yahweh is through the intermediary of the religious functions of prophets and priests. The attempt in this section is thus to present a brief overview of the religious functions of prophets and priests in the HB/OT and thus of Ancient Israel and Judah. On the one hand, the Hebrew Bible/Old Testament (HB/OT) has an abundance of material for prophets and

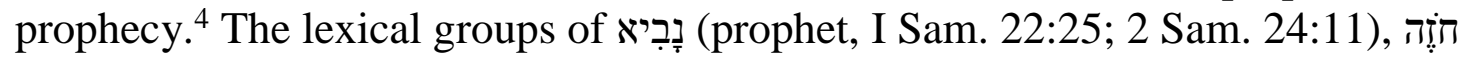
and רֶֶ (seer, 2 Sam. 24:11; I Chr. 29:29; and I Sam. 9:9, 19; I Chr. 29:29) used interchangeably and in connection with each other functioned in different contexts. Thus, the primary and basic Hebrew word for prophet in the HB/OT which reinforces the appropriate means of understanding and articulating the will of the divine, namely the ecstatic prophet is connected with the verb "to call," and points to someone called by God or who called others on God's behalf. Essentially, a divine call authenticated a prophet's ministry and instilled authority and credibility to his words or messages. ${ }^{6}$ By divine revelation, a prophet could have insight into deep spiritual issues that others could not ordinarily see and understand. ${ }^{7}$

$4 \quad$ Lester L. Grabbe, Priests, Prophets, Diviners, Sages: A Socio-Historical Study of Religious Specialists in Ancient Israel (Valley Forge: Trinity Press International, 1995), 82.

5 Diana V. Edelman, "From Prophets to Prophetic Books: The Fixing of the Divine Word," in The Production of Prophecy: Constructing Prophecy and Prophets in Yehud (eds., Diana V. Edelman and Ehud Ben Zvi; London, Oakville: Equinox Publishing Ltd., 2009), 29-54 (30).

6 For a description of the call of prophet, see Isaiah 6:8-9; Jeremiah 1:4-10; Amos 7:14-15; Jonah 1:1-2. Isaiah for example willingly accepted God's call and Jeremiah disputed with God. While Amos was enthusiastic, he was astonished by the call. In Jonah's case, he heard the call and attempted to run away.

7 Paul L. Redditt, Introduction to the Prophets (Grand Rapids, Michigan: William B. Eerdmans Publishing Company, 2008), 5; H. Shalom-Guy, "The Call Narratives of Gideon and Moses: Literary Convention or More?" JHS 11/11 (2011): 2-19 (10). 
Prophets and their assumed declarations were very vital to the traditions of the HB/OT and the religion of Ancient Israel and Judah. Within this traditional framework, one grapples with a stream of ambivalent viewpoints which are both positive and negative. Some of these prophets are viewed as genuine prophets while others are considered as false. ${ }^{8}$ Prophets who are regarded as true messengers of God, on the one hand, are those who fruitlessly alerted and warned the people of the consequences of their behaviours. On the other hand, those who deceptively swindled the people are regarded as fraudsters and false. ${ }^{9}$ These traditions are not necessarily actual historical portrayals of the true character of prophecy but rather they are a mirror of prophecy constructed by later awareness. ${ }^{10}$

The basic and normative role of prophet in the HB/OT and thus Ancient Israel and Judah was that of an intermediary; transmitting Yahweh's word to the people. ${ }^{11}$ They undoubtedly and absolutely based their messages upon direct encounter and personal relationship with God and at God's own initiation. The authority of their message דָבָר יהוה (the word of Yahweh) came to them practically as an unbiased, real and definite entity through Yahweh's Spirit (2 Sam. 23:1-3; Ezek. 11:5; Mic. 3:8), ${ }^{12}$ dreams and visions (Num. 12:6; Hos. 12:10). Consequently, prophets were key personae empowered by God as channels for the transmission of his will to the human society of their time. Their actions and declarations gave their community momentary foretastes of the consequences of the attitude of their leaders. ${ }^{13}$ Beyond their involvement in

8 Alphonso Groenewald, "Prophetic Witness in the Hebrew Bible: From Prophetic Word to Prophetic Books," in Prophetic Witness: An Appropriate Contemporary Mode of Public Discourse? (eds., Heinrich Bedford and Etienne de Villiers; Munster: LIT Verlag, 2011), 29-46 (31); Matthijs J. De Jong, "The Fallacy of 'True and False' in Prophecy Illustrated by Jer. 28:8-9," JHS 12/10 (2012): 1-31. For textual reference regarding the distinction between true and false prophets see the following passages: Ezek. 13:1-12; 22:28. Jer. 29:8-9; Deut. 18:9-14; Mic. 3:5, 11; Isa. 28:7; Zeph. 3:4; Jer. 23:16.

9 Matthijs J. De Jong, "Why Jeremiah is not among the Prophets: An Analysis of the Terms נבאים an the Book of Jeremiah," JSOT 35/4(2011): 483-510 (495-496).

10 Matthijs J. De Jong, Isaiah among the Ancient Near Eastern Prophets: A Comparative Study of the Earliest Stages of the Isaiah Tradition and the Neo-Assyrian Prophets (VT Sup 117; Leiden: Brill, 2007), 323.

11 Pancratius $C$. Beentjes, "Constructs of Prophets and Prophecy in the Book of Chronicles," in Constructs of Prophecy in the Former and Latter Prophets and Other Texts 4 (eds., Lester L. Grabbe \& Martti Nissinen; Atlanta: Society of Biblical Literature, 2011), 21-40 (37).

12 Johannes Lindblom, Prophecy in Ancient Israel (Oxford: Blackwell, 1962), 174179; Daniel I. Block, "Empowered by the Spirit of God: The Holy Spirit in the Historiographic Writings of the Old Testament," SBJT 1/ 1 (1997): 41-52 (43).

13 Victor H. Matthews, Social World of the Hebrew Prophets (Peabody; Massachusetts: Hendrickson Publishers, Inc., 2001), 21-26. 
national affairs ${ }^{14}$ prophets counselled and advised kings to walk in the ways of God and most times confronted and challenged them. They were actively involved in significant national moments, like those of political-military catastrophes occasioned by the menace of enemies, internal power conflicts and wars. ${ }^{15}$

A shift of emphasis is, however, visible among the eighth-century prophets. ${ }^{16}$ While they still had oracles from God to announce to kings and other leaders of their nations, their prophetic messages were directed more pointedly towards the people and society generally. This may be as a result of deteriorating existential challenges confronting the nations. The failure of kings and leaders of the nations to maintain righteousness and justice necessitated prophetic oracles of impending judgment. In this regard, they were basically preachers who announced Yahweh's word with different dramatic and rhetorical means to invite the attention of their listeners and drive home their message. ${ }^{17}$ These prophets,

14 Moses who described as the prophet par excellence, or "the prophet of prophets," was national leader. Karel Van der Toorn, Scribal Culture and the Making of the Hebrew Bible (London: Harvard University Press, 2007), 34. This description of Moses as a prophet per excellence is based on Deuteronomy 18:15; 34:10, although his burning bush experience (Ex. 3) also suggests a prophetic function. Herbert B. Huffmon, "A Company of Prophets: Mari, Assyria, Israel," in Prophecy in its Ancient Near Eastern context: Mesopotamian, Biblical, and Arabian Perspectives (ed., M. Nissinen, SBLSS Vol. 13; Atlanta, Society of Biblical Literature, 2000), 47-70 (63); Reinhard Achenbach, "A Prophet like Moses" (Deut 18:15) - "No Prophet like Moses" (Deut 34:10): Some Observations on the Relation between the Pentateuch and the Later Prophets," in The Pentateuch: International Perspectives on Current Research (eds., T.B. Dozeman, K. Schmid and B.J. Schwartz;, Tubingen: Mohr Seibeck, 2011), 435458 (441).

15 Before embarking on a military operation, a king consulted with his prophets (I Kgs. 22:6-7; 2 Kgs. 3:11). Elisha is said to have given military intelligence delivered to him by God to the king of Israel during his war with Syria (2 Kgs. 6:8-12). De Jong, Isaiah among the Ancient Near Eastern Prophets, 342.

16 The eighth-century prophets are otherwise known as "classical" prophets. Although there appear to be a slight shift in emphasis, it is, however, difficult to create a clear and significant distinction between them and earlier prophets. See comments by Horst D. Preuss, Old Testament Theology (Louisville: Westminster John Knox, 1996), 2: 70-73; Rolf Rendtorff, The Canonical Hebrew Bible: A Theology of the Old Testament (Trans., David E. Orton; Tools for Biblical Study, 7; Leiden: Deo Publishing, 2005), 157-162.

17 The prophets sometimes presented their messages using allegorical forms or parables or "prophetic symbolism." For example, Isaiah went "naked and barefoot" (Isa 20:2-3) to dramatize the fate of the Egyptians and Cushites at the hands of the Assyrians. For other illustrations see Jer. 13:1-11; Ezek. 4:1-6; Robin L. Routledge, Old Testament Theology: A Thematic Approach (Apollos: Inter-Varsity Press, 2008), 212-213. 
when reproaching the political establishment and religious institutions and their leaders, they simultaneously indict other prophets and priests. This goes to show that prophets may also have had a formal position like the national leaders. ${ }^{18}$ Consequently, this formal position may have compelled them to compromise with their employers thus lowering the standard of the divine demands. ${ }^{19}$

Within the HB/OT on the other hand is the convergence of a broad spectrum of different priestly groups - Levitical, Zadokite and Aaronic priestly traditions. ${ }^{20}$ A pan-Levitic or Deuteronomist priestly ideology holds that all Levites are priests who are commissioned with the offerings and sacrificial aspects of the cult. The biblical sources for the Levitical priestly traditions are those of Deuteronomy (18:1-8), viz. Jeremiah (33:21), and Malachi (1:6-2:10) ${ }^{21}$ Zadokite exclusivism is noticed in Ezekiel's extreme anti-Levitic polemic and narrowest definition of legitimate priesthood in the HB/OT (Ezek 40:46; 44:15$31 ; 43: 19 ; 48: 11){ }^{22}$ Aaronic priestly ideologies are developed in priestly sources (Ex 28:40-43; 29:1-9; Num 18:1-4), in Ezra-Nehemiah and Chronicles (Ezra 10:39; Neh 12:44-47; 2 Chr 26:18; 29:21; 31:19; 35:14). Typically, both the Jewish and Christian traditions associate Israel's priestly groups with the temple in Jerusalem. In this tradition, the descendants of Moses' brother, Aaron are regarded as exclusive and distinctive extraction dedicated to the worship of Israel's God namely, Yahweh, and commissioned with the teaching of the knowledge and will of Yahweh. In his examination of priesthood in Ancient Israel Mark Leuchter notes that,

The social, textual, mythic and political concerns of Israel's priestly groups are evident throughout the biblical record, and reveal the depth of influence the priesthood exerted not only on the formation of the Bible but on the growth of Israelite religion into early Judaism . . .

18 (See for example Isa. 28:7; Jer. 2:26; Ezek. 7:26; Mic. 3:11; Neh. 9:32; Zech. 7:13). The expression 'prophet of Israel' (Ezek. 13:2), suggests an official position. Beside Amos 7:14, where there is the reference ברן־נבריא (son of the prophets or member of a prophetic guild), such references are lacking in the classical period. This may account for the fact that all such prophetic groups had become 'official.'

19 De Jong, "The Fallacy of 'True and False' in Prophecy Illustrated by Jer. 28:8-9," 4.

20 For details of explanation regarding these priestly circles see Dongshin Don Chang, Phinehas, the Sons of Zadok, and Melchizedek: Priestly Covenant in Late Second Temple Texts (LSTS 90; New York: Bloomsbury T \&T Clark, 2016), 55-65.

21 Saul M. Olyan, “Ben Sira's Relationship to the Priesthood,” HTR 80 (1987):261286 (273).

22 Zadokite priestly ideologies are also reflected in Chronicles with Hasmoneans development (I Chr 24; 29). The non-inclusion of Abiather, one of the pillars of David's priestly establishment in this record is perhaps due to Abiather's assistance of Adonijah rather than Solomon (I Kgs 1:7; 2:26-27). Alison Schofield and James C. Vanderkam, "Were the Hasmoneans Zadokites?" JBL 124 (2005):73-87 (86). 
priests functioned as mediators between the realm of the divine and the realm of common activity and experience. ${ }^{23}$

In the light of communal responsibility and religious interest, the priests' sphere of influence is thus represented and embodied by the temple and everything that is associated with it. ${ }^{24}$ Priests were mediators between Yahweh and the larger human population, providing opportunities for individuals, families, groups and communities to make offerings, offer prayer requests and carryout religious responsibilities as occasions demand. Consequently, Leuchter explains the religious function of priests thus:

Priests officiated at various rituals, oversaw sacrifices, and regulated communal festivals, ensuring that society engaged in its due diligence to YHWH in exchange for that deity's protection, support and blessings. Priests were thus the representatives of the people to YHWH, but priests also stood as representatives of YHWH to the people in this context, identifying and clarifying the purpose of a given ritual, reifying tradition by the recitation of laws or the record of legal precedent, and preserving the catalog of hymns and prayers that the deity would expect or even demand be recited at specific occasions. ${ }^{25}$

This important function of safeguarding cultic and ritual aspects of the temple makes prophetic indictment of unethical standards of behaviour very pointed in its denunciations with rhetorical features that compel their audience and readers to reflect on the significance of ethical standards of cultic behaviour. Besides their religious function of supervising and guarding the cultic life of the people, priests were also entrusted with judicial responsibility. Priests arbitrated between families and social groups. Their judicial functions which are preserved in Deuteronomy 17:8-13 included issues such as land differences and disputes, marital faithfulness and responsibilities, inheritance and civil relations. By this function, they maintained the sacredness of daily human life within society as much as they regulated and guarded the cultic life of the people. ${ }^{26}$

One other integral aspect of priestly functions is the educational responsibility. Priestly instructional or pedagogical duty is hinted at in quite a number of biblical materials. Priestly commission to educate the people is found in the priestly material of Leviticus 10:10-11. Here the priests are charged with the responsibility of establishing a distinction between the holy and the profane, and between the unclean and the clean and to teach (iּרוֹרוזת) all the children of

23 Mark A. Leuchter, "The Priesthood in Ancient Israel," BTB 40/2 (2010):100-110 (100). DOI: 10.1177/0146107910364344.

24 Bohdan Hrobon, Ethical Dimension of the Cult in the Book of Isaiah (BZAW 418; Berlin/New York: De Gruyter, 2010), 10.

25 Leuchter, "The Priesthood in Ancient Israel, 101.

26 Leuchter, "The Priesthood in Ancient Israel, 101. 
Israel the statutes which Yahweh has spoken to them through his servant, Moses. Within the background of Moses' blessing in Deuteronomy, the family of Levi is singled out for praise on account of its faithfulness in discharging their instructional responsibility (Deut 33:10). Both prophetic literature (Isa 7:26; Ezek. 44:23; Jer. 18:18) and historical writings of Ezra-Nehemiah (Ezra 7:10; Neh 8:1-8,11) and Chronicles (2 Chr 17:7-9) attest to the teaching aspect of the priestly function. ${ }^{27}$

While prophets and priests functioned in different spheres of the communal and religious life of Ancient Israel and Judah, it appears that individual prophets assumed prophetic status in the Jerusalem temple cult together with the priests. This relationship is seen in individual and cooperate religious service of lamentation (see, for example, Obadiah, Habakkuk and Zechariah). The resentful declaration of Jeremiah's opponents (Jer 18:18) indicates that a close relationship existed among the three religious authorities; priests, sages and prophets. The same relationship is emphasised in Ezekiel 7:26:

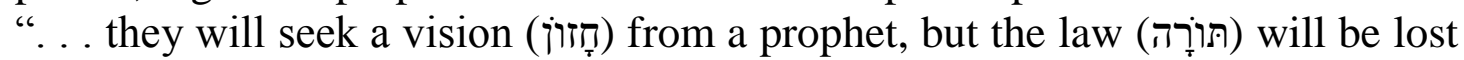
from the priest and counsel (يֶָָ) from the elders." Both prophets and priests obviously spoke with authority and evidence of unethical practices is observed in their common element of prophecy and teaching; namely, the giving of (Isa 1:10;8:16, 20; 30:9; Zech 7:2-14). They announced a number of their communal oracles in the temple's court, whether or not they were officially involved in the cult (Amos 7:13; Jer 7:2; 26:2; 36:5-6; Hos 4:4-5; Hag 1:3-12).

Nevertheless, and in general, one sees that the classical or cult-critical prophets appear to be fundamentally opposed to the official temple prophets and priests (Isa. 28:7ff; Hos. 4:4-10; Mic. 3:5-8, 11; Jer. 23:11; 26:7f; Ezek. 7:26; 22:25f) and the priests were discontented with the interference of prophets like Amos (7:10-17) and Jeremiah (20:1-2; 26:8; 29:24-28). Amos pungently rejects every attempt to associate him with official temple prophets and priests' groups (7:14). He rather emphasises his independent status over against official temple structures. Notwithstanding, in all their interactions, the manner in which the knowledge of Yahweh's word is held by them remains unique. They claim both divine authority and priority and are viewed together in an imaginative tension. The HB/OT and the religion of Ancient Israel and Judah revolve around the two poles; the prophetic and the priestly.

\section{CONTEXT OF MICAH'S STUNNING INDICTMENT}

Micah's indictment of the charismatic and cultic Judean's self-centred and selfserving leadership is clearly rooted within a nexus of religious and cultural tensions as well as political and socio-economic relatedness. Micah's superscription (1:1; with supportive reference in Jer 26:18), like the rest of

27 L Lena-Sofia Tiemeyer, Priestly Rites and Prophetic Rage: Post-exilic Prophetic Critique of the Priesthood (FAT 2, 19; Tubingen: Mohr Siebeck, 2006), 113-115. 
similar prophetic books (Amos, Hosea, and Isaiah), locates the prophecy to the period of Neo-Assyria political and ideological dominance of the $\mathrm{ANE},{ }^{28}$ and control of the fragmented and disjointed kingdoms of Israel and Judah. ${ }^{29}$ The book's prologue introduces the traditional character Micah the Morasthite (1:1, 14; cf. Jer 26:18) ${ }^{30}$ whose prophetic ministry spans the period of three Judean kings: Jotham (743-735B.C.E.), Ahaz (735-715B.C.E.) and Hezekiah (715687B.C.E.). ${ }^{31}$ The major political events that shaped the backdrop to Micah's ministry are found in the records of 2 Kings 15-19. These texts relate various Assyrian swipes on the region including the capture of Samaria in 722/721 BCE and the siege of Jerusalem in 701 B.C.E. ${ }^{32}$

He is identified as a younger contemporary of Isaiah (Isa $1: 1),{ }^{33}$ both of whom prophesied in Jerusalem and Judah, the home of royal and Zionist theology. ${ }^{34}$ While Isaiah resided in Jerusalem, the capital city, Micah seems to be languishing in the countryside of Moresheth, a dependency of MoreshethGath. $^{35}$ This environmental setting is reflected in the writings of the two prophets. On the one hand, Isaiah writes as one who is familiar with society and patterns of capitals and with a passionate interest in political developments of the time. Micah on the other hand, speaks as the "man of the people" who cast his fate with the less privileged individuals of his land and become a prophetic

28 Donald E. Gowan, Theology of the Prophetic Books: The Death and Resurrection of Israel (Louisville: Westminster John Knox Press, 1998), 50; Iain Provan, V. Philips Long and Tremper Longman III, A Biblical History of Israel (Louisville: Westminster John Knox Press, 2003), 271-273.

29 David M. Carr, An Introduction to the Old Testament: Sacred Texts and Imperial Contexts of the Hebrew Bible (Chichester: Blackwell Publishing, 2010), 117; David M. Carr, The Formation of the Hebrew Bible: A New Reconstruction (Oxford: Oxford University Press, 2011), 318.

30 Reference to Micah in this study does not imply the imagined eighth-century prophet but the literary character depicted in the book or the Book of Micah.

31 Devadasan N. Premnath, "Amos and Hosea: Sociohistorical Background and Prophetic Critique," Word \& World 28/ 2 (2008): 125-132 (126); James D. Nogalski, The Book of the Twelve: Micah-Malachi (Macon, Georgia: Smyth \& Helwys Publishing, Inc., 2011), 511.

32 Julia M. O'Brien, Micah (Wisdom Commentary 37; Collegeville, Minnesota: Michael Glazier Book, 2015), 2.

33 See Robert V. Huber, Robert M. Grant and Tracey Grant-Starter, eds., Who is Who in the Bible (Pleasantville; New York: Reader's Digest Association, Inc., 1994), 295; Philip P. Jenson, Obadiah, Jonah, Micah: A Theological Commentary (LHBOTS 496; New York; T \&T Clark, 2008), 95.

34 Carr, An Introduction to the Old Testament, 117.

35 Francis I. Andersen and David Noel Freedman hold that the name was assigned to Jerusalem, probably as a "derogatory" term employed by the city-dweller to refer to the "rustic." Francis I. Andersen and D. N. Freedman, Micah: A New Translation with Introduction and Commentary (AB 24E; New York: Doubleday, 2000) 109. 
theologian and courageous advocates of the rights of the disadvantaged. He appears almost exclusively as an ethical and religious advocate. ${ }^{36}$ However, Micah does not offer his readers so much information about the Neo-Assyria influence. "He mentions, indeed, the Assyrians, but only as a mere foe, not as a power which might tempt his countrymen to embark upon a perilous political enterprise, and he raises no warning voice against the danger to Judah of the Egyptian influence."37

Although Assyrian rule has been characterised as fear-invoking cruelty, the reality is that such violence, depending on the circumstances, could have diplomatic intentions associated with it. Assyria's subjugation and rule were, nonetheless, economically motivated. ${ }^{38}$ Assyrian economy was essentially maintained by both tributes received from subjugated peoples and ill-gotten gains of their armies. As Assyrian business partner, the destruction of Israel resulted in drastic loss of goods, stocked produce, revenue and trade. Supplementing this economic recession was the devastating imposition of tributes and taxes. In attempts to pay, Ahaz had to empty the temple and its treasury even as regular temple services had stopped and the combination of varying religious practices had developed in support of the king ( $2 \mathrm{Kgs} 16: 3-18$; 2 Chron 28:23-25; Mic 5:12-14). ${ }^{39}$ While idolatrous syncretism existed as a result of the Assyrians' subjugation and that religious reform could not hold as long as Judah was under Assyria's control, Micah's preaching may have been responsible for Hezekiah's religious reforms (2 Kgs 18:4-5; 2 Chron 31). ${ }^{40}$ The greatest tension, however, was that of socio-economic contradiction and transgression. Micah decries the manner in which the less privileged in his community were treated by the wealthy and the collusion of the political, social, and religious leaders in the transgressions that he saw.

The agricultural economy of Israel and Judah that had hitherto functioned at a more sustenance level now assumed an administratively large scale and a well-controlled one. ${ }^{41}$ The gradual and steady growth of the economy is reflected in what John Bright refers to as "a dramatic reversal of fortune" and the "heights

36 Samuel R. Driver, An Introduction to the Literature of the Old Testament (New York: Charles Scribner's Sons, 1913), 326.

37 Driver, An Introduction to the Literature of the Old Testament, 326. However, brief historical mention of Egypt is found in 6:4; while in 7:12, 15, restoration evidence highlights Egyptian presence.

38 Smith-Christopher Daniel L, Micah: A Commentary (OTL. Louisville: Westminster John Knox, 2015), 6.

39 John Bright, A History of Israel, 3rd ed. (Philadelphia: Westminster, 1981), 277.

40 Bright, A History of Israel, 278.

41 Marvin L. Chaney, "The Political Economy of Peasant Poverty: What the EighthCentury Prophets Presumed but did not State," in The Bible, the Economy, and the Poor, eds., Ronald A. Simkins and Thomas M. Kelly; JRS Supplement Series 10 (2014): 3460 (36). URL: http://purl.org/JRS 
of power and prosperity." 42 This shift of production control obviously had implications on the social realities as it enhances large scale production and estates and disadvantaged traditional methods of agriculture as well as community members' social relation. Though this development benefited the elites nevertheless, it occasioned varying degrees of economic contradictions and transgressions. It is interesting to observe how "the wealthy" manipulated and unjustly appropriated the rights and privileges of "the poor" in a legal structure that was otherwise based upon Yahweh's blueprints for covenant community living. ${ }^{43}$

In addition to shortfalls in the ethical standards in Micah's community, the dual religious functionaries (the prophetic and the priestly) who ought to have stood in the gap and offer a solution for the situation lived with perverted theological perspectives and unethical religious practices. They preached a positive and optimistic message of immutable and infinite grace (2:7). Rather than speaking with the priority and authority of their divine commission and through their common element of prophecy and teaching they combined with the social elites and community leaders and thus traded their sacred commission for symbols of wealth and power. Through their inverted oracles and commercialised teachings $(3: 3-8,11)$, temple worship became an obstacle to genuine religious experience, as sacrifice and rituals without the practice of justice were empty and worthless (6:6-8). The following sections examine Micah's indictment of religious leaders (prophets and priests) and conclude with resulting implications.

\section{MICAH'S INDICTMENTS OF JUDEAN PROPHETS AND PRIESTS (MICAH 3:5-7, 11)}

The highlighting of wrongdoers and wrongdoing begun by Micah in Chapter 2 though their specific identities remains elusive and came to a point of identification in Chapter 3. As a follow-up reaction to the judgement sentence of 2:6-11, Micah 3 addressed Judah's ruling classes, who - according to 3:1 - ought

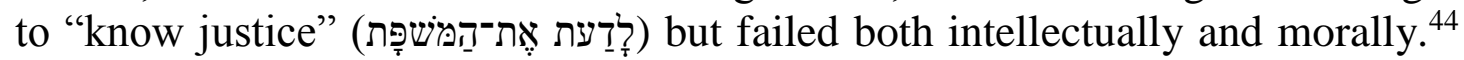
Although Micah addressed the collective failure of the various heads of Judah (civil; elders, princes and judges, charismatic; prophets, and cultic; priests - 3:1$4,9,11)$, the concern here is the collusion of the prophetic and priestly groups. The specific accusation emanating from these verses is that of trading their

42 Bright, A History of Israel, 252.

43 Otto Kaiser, Isaiah 1-12: A Commentary (London: SCM Press LTD, 1972), 65; James L. Mays, Micah: A Commentary (London: SCM Press Ltd., 1976), 64; Ralph L. Smith, Micah-Malachi (Word Biblical Commentary, Vol. 32; Waco: World Books, 1984), 24.

44 Jacob Mignon, The Conceptual Coherence of the Book of Micah (JSOT Sup 322; Sheffield: Sheffield Academic Press, 2001), 84-85. 
privilege of mediating Yahweh's word to the people for economic gains. The analyses below reveal the depth and gravity of their abuse of privilege.

\section{Perverted Prophetic Oracles (3:5-7 $)^{45}$}

3:5 Thus says the LORD concerning the prophets who lead my people astray;

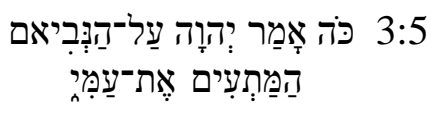

When they have something to bite with their teeth, They cry, "Peace

But against him who puts nothing in their mouths, they declare holy war.

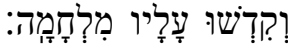

3:6 Therefore, it will be night for you without vision, and darkness for you, without divination.

And the sun will go down on the prophets, and the day will become dark over them.

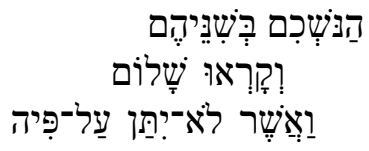

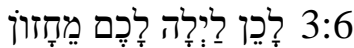

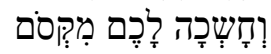

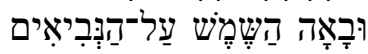

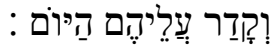

3:7 The seers will be humiliated and the diviners will be embarrassed.

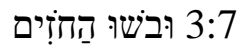

and they will all cover themselves up to their moustache, because there is no answer (from) God.

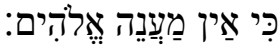

As in chapter 2, where Micah reproached the prophets (2:6-11) after a sharp sentence on the greedy land magnates (2:1-5), so also in chapter 3 a judgement oracle against the greedy prophets $(3: 5-8)^{46}$ follows against greedy leaders $(3: 1-$ 4). The structure of this sub-unit is clear: the messenger formula with inserted addressees (3:5a), the accusation $(3: 5 b)$ and judicial sentence $(3: 6-7) .{ }^{47}$ In this section, Micah turns his attention to those prophets who have misled the people into thinking that they will soon find peace, as long as the people are willing to pay them. The oracle denounces these prophets, whose pessimistic attitude allows them to take advantage of the people's trust; who come to them to request a prophecy about the future. ${ }^{48}$

The first paragraph of this unit begins with the prophetic messenger

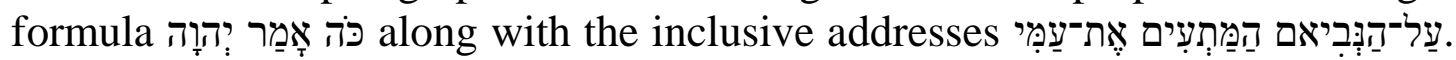
The addresses are described and characterised by verbal participles as in $3: 2 ; 9$ 10. The common noun with the construct suffix first person (my people) indicates the whole nation and suggests that Yahweh is speaking but through his messenger. While the immediate context $(3: 1-4)$ and the concluding section

45 Except otherwise indicated, the translations in this article are from the New American Standard Bible (NASB).

46 Andersen and Freedman, Micah: A New Translation, 359.

47 Waltke, A Commentary on Micah, 168.

48 Nogalski, The Book of the Twelve: Micah-Malachi, 547. 
$(3: 9,12)$ reveal that the lager issue is that of the administration of justice and establishment of equity in society generally, Micah's indictment here is on Judah's charismatic leadership and twisted prophetic oracles (3:5-8). The participles describing these prophets show that they cause the people to wander off, go astray, feed on them and announce peace when Yahweh has not allowed such announcement. The verb תָָּ (to err, wander) is used in the Hiphil participle. It conveys the idea of misguiding people to wander morally or mentally (cf. Deut $13: 6 ; 27: 18)$. "The implied norm is the moral and religious path that the prophets

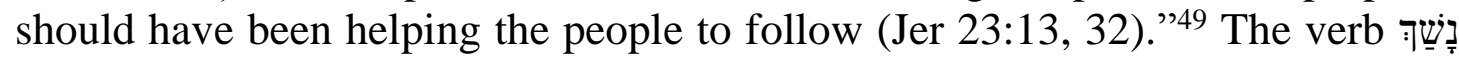
(to bite) usually describes the action of serpent biting or wounding (Gen 49:17; Num 21:8, 9; Amos 5:19; 9:3) rather than ordinary eating. However, the

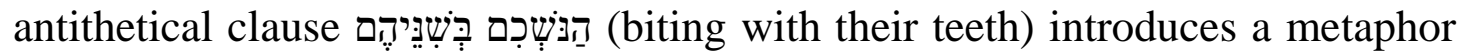
of food and may imply that these prophets may not be ignorant of the mischief of the leaders but are active beneficiaries of the systemic order. Thus, the comparison of the attitude of the prophets with extortionate business practices is in order. Like the judges and priests, the prophets too were in business to make maximum profits. ${ }^{50}$

The motivation or driving force of these prophets for ministry is that which goes into their mouths; namely the service fees paid to them by those who trusted them as Yahweh's vehicle for the transmission of his will and thus requested direction concerning the future at their mouths. The well-fed or well-

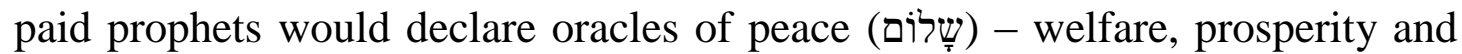
general well-being, "But against the one who could not put anything in their

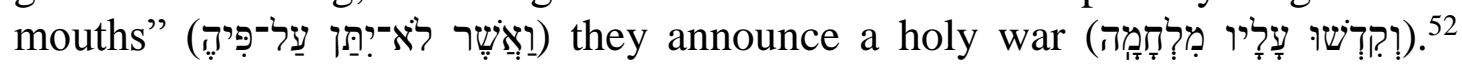

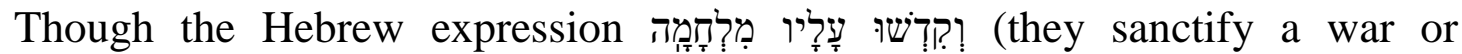
consecrate a war) may have some allusions to religious rites (cf. Jer 6:4; Joel 3:9), for Micah in all probability implies that when the customary service fees are not given or withheld, these prophets announce an inevitable calamity; and they do so in the name of Yahweh (cf. Jer 23:16). That these prophets exchange

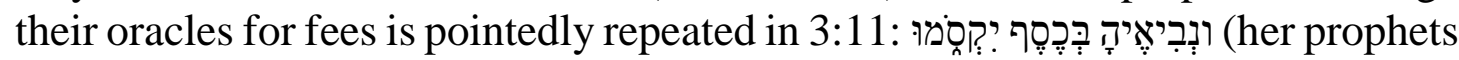
divine for money). Thus, the clear ideological reasoning is that these prophets

\footnotetext{
49 Jenson, Obadiah, Jonah, Micah, 134.

50 Andersen and Freedman, Micah: A New Translation, 362-363.

51 The Hebrew term שָל (peace) is regarded as the OT's richest word to denote the blessings of salvation (Deut 28:1-14). It "included bodily health, social harmony, economic plenty, and political security. The prophets promised such peace, but without its essential ethical and religious foundations (Jer 6:14; Ezek 13:10).” Jenson, Obadiah, Jonah, Micah, 135.

52 Hans W. Wolff, Micah: A Commentary (trans. Gary Stansell; Minneapolis: Augsburg Fortress, 1990), 102.
} 
and their oracles are unreliable since their visions are motivated by greed and not from Yahweh. ${ }^{53}$

In 3:6-7, Micah pronounces Yahweh's sentence on these prophets for their transgressions. "'Night', 'darkness', 'the sun going down', 'the day growing dark' are a series of images for the experience of distress and dereliction." 54 The image of loss of sight is explored first in 3:6, symbolizing the absence of Yahweh for the prophet. Since the prophets cannot see in darkness, this image conveys the loss of power for these prophets and specifies how the visionaries will be discredited. ${ }^{55}$ Micah 3:7a coveys the removal of speech from those who make their livelihood by speaking. A prophet without vision and speech is worthless. One of the essential media of revelation for the prophets was חזָז (vision); a legitimate Israelite way of discovering God's will (Prov 16:10). It has a similarity to an inspired dream (Isa 27:9; cf. Num 12:6-8) and a positive reference to קָָס (to practice divination) (Jer 27:9; Ezek 21:21) which was sternly condemned (Deut 18:10, 14; 1 Sam 15:23; 2 Kgs 17:17). ${ }^{56}$ Since prophets see vision from Yahweh and speaks on his behalf, the removal of sight and speech goes to the heart of their identity. This sentence of judgement removes their ability to function as prophets because they falsified and perverted their privilege to act as Yahweh's spokesmen and thus were deluded by Yahweh. ${ }^{57}$

The implication of this dark silence from God will be the disgrace of the prophets (3:7). The two terms: בִּפּר (shame) (disgrace) are often rendered as embarrassment and humiliation (Job 6:20; 19:3; Pss. 6:10; 22:5; 44:7; Prov. 14:35). ${ }^{58}$ These prophets will be ashamed of their loss of position and influence, they will be exposed as unclean, and God will not answer them when they cry

\footnotetext{
53 Nogalski, The Book of the Twelve: Micah-Malachi, 547.

54 Mays, Micah, 84.

55 Nogalski, The Book of the Twelve: Micah-Malachi, 548; Andersen and Freedman, Micah, 376.

56 Tָז is also a technical term used to describe the contents of a prophetic book especially in its superscription. As a way of describing the contents of a prophetic book Stephen G. Dempster notes, "Both noun and verb are used in Isa 1:1; the verb is used in Amos 1:1; Mic 1:1; and Hab 1:1; the noun is used in Obad 1 and Nah 1:1. The rest of the prophetic inscriptions use the term 'word of Yahweh' (Jer 1:2; Ezek 1:3; Hos 1:1; Joel 1:1; Jonah 1:1; Zeph 1:1; Hag 1:1; Zech 1:1; Mal 1:1). The term 'burden' also seems significant (cf. Hh 1:1; Mal 1:1)." Stephen G. Dempster, Micah (The Two Horizons Old Testament Commentary; Grand Rapids, Michigan: William B. Eerdmans Publishing Company, 2017), 112.

57 Bruce K. Waltke, A Commentary on Micah (Grand Rapids: Eerdmans, 2007), 169170; Nogalski, The Book of the Twelve: Micah-Malachi, 548.

58 Smith-Christopher, Micah: A Commentary, 117.
} 
for the restoration of their gifts. ${ }^{59}$ As a result of this embarrassment and humiliation, they will "cover themselves up to their moustache" (v.7b). This is an expression of wonder and amazement at the action of God or they will have nothing to say. They will cover their faces with sorrow to hide their shame when their separation from Yahweh becomes public knowledge (cf. Lev. 13:45; Ezek. 24:17, 22). ${ }^{60}$ Like the ruling elders who gruesomely flayed Yahweh's people in Micah's depiction (3:1-4) and who will experience Yahweh's absence, these well-fed prophets are apprehended in a darkness of their own creation. They will lose their ability to prophesy and the consequence of their prophetic bankruptcy will be disappointment and dishonour (בפוש (רפוּ) and humiliation, scorn or mockery (דָפָר). Since their oracles are considered to be delusional, they will lose the respect of the people and become a laughingstock.

\section{Commercialised Priestly Teachings (3:11)}

3:11 Her leaders who pronounce judgment for a bribe, and her priests who instruct for a price, and her prophets who divine for money.

Yet they lean on the LORD saying

"Is not the LORD in our midst?

No calamity will come upon us."

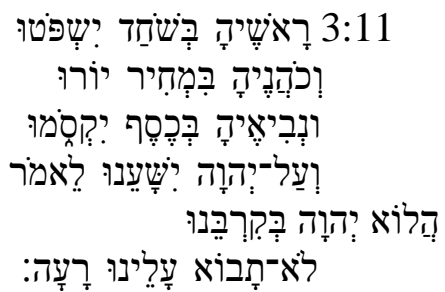

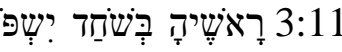

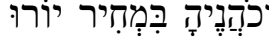

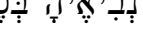

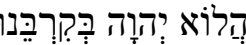

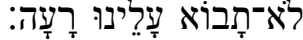

In 3:11, Micah levels his accusations against other sections of the nation, as the prophets, judges and priests also request their charges. As earlier stated, priests were charged with the responsibility of supervising and guarding cultic the life of the people, arbitrating between families and social groups and teaching and expounding the Law. They were expected to gratuitously enforce compliance with ethical standards as criteria for admission into the sanctuary and instruct the people in the ethical traditions of their covenant with Yahweh (Lev 10:11; Deut $17: 8-13 ; 33: 30){ }^{61}$ But these priests, like their religious counterparts - the prophets - perverted this privilege by commercialising their religious teachings for selfish interests. Those who were to uphold religious traditions and order were seen participating in a tyranny of transgression. ${ }^{62}$ Though the support for the priests was through the divinely apportioned tenth in Israel (Num 18:20-21), both whether provided for or not, these priests traded the grace of God upon receipts of covetous fees. The most incriminatory aspect of their attitude was that they claimed to be relying on Yahweh, while they were violating his laws and

59 Bruce K. Waltke, "Micah" in The Minor Prophets: An Exegetical and Expository Commentary (ed., T. E. McComiskey; Grand Rapids Mich.: Baker, 1993), 2: 591-764 (664-665).

60 Alfaro, 37-37.

61 Gerhard von Rad, Old Testament Theology, vol. 1 (London: Oliver \& Boyd 1962), 244.

62 Leslie C. Allen, “Micah's Social Concern,” Vox Evangelica 8 (1973): 22-32 (28). 
defrauding the people. Their perspectives toward what they do are regulated by their own sense of entitlement. They mistakenly believed their positions of power and privilege would protect them. Thus they traded their responsibility to rule, teach, and speak for Yahweh for symbols of power and wealth.

\section{E. CONCLUDING ETHICAL IMPLICATIONS}

What ethical message does Micah's indictment of Judah's charismatic and cultic leadership offer his intended readers and re-readers? Granted that Micah's indictment bears the stamp of Ancient Israel and Judah's religious selfconsciousness and theocratic society rooted in social and historical realities, ${ }^{63}$ reflection on Micah's indictment generates the following ethical concerns for the practice of religious faith within a context of socio-economic contradictions.

\section{Abuse of Position and Privilege}

In every society, there exist men who are appointed to certain privilege position of leadership with the power of influence over others. The nature and direction of such influence obviously depend upon the content of the leaders' character. The more outstanding a leader is among his community, the more comprehensive it is within the circle and scope of his influence. Prophets and priests were men of great religious influence and power in Ancient Israel and Judah's religious society. But contrary to expected norms and standards, Micah's indictment reveals how Judah's charismatic and cultic leadership grossly abused their position and privilege. The thematic cornerstone of Micah's indictment is the abuse of position and privilege in the name of Yahweh. Micah decries them for degrading their sacred commission and function through the mercenary attitude in discharging their duties. Their failure in providing the required godly leadership led many to wander off in misery and destitution and ultimately incurred Yahweh's judgment upon them and their nation $(3: 4,12) .{ }^{64}$

Like it was in Ancient Judah and Micah's time, there is of a necessity a position of religious prominence to occupy in every religious and faith community. The desire to occupy such positions must not be for the sake of being regarded as prominent, powerful and to utterly sacrifice the rights and privileges of the people on the altar of greed. Such desire must, however, be born out of a genuine interest to climb above self-centred ambition; a desire that will guarantee confidence rather than thrusting people into the sphere of confusion and misery. Micah's indictment of Judah's charismatic and cultic leadership places a strong ethical caution on religious leaders at every level of ministry regarding the way and manner they consider their position and exercise their leadership influence. Micah underscores that the privilege and responsibility of ministry require men of sound and profound moral character that will consistently and reliably mediate

\footnotetext{
63 Allen, "Micah's Social Concern," 32.

64 Nogalski, The Book of the Twelve: Micah-Malachi, 551.
} 
Yahweh's word and ministerial functions (3:8). Since self-centeredness, greed and unrighteous ambition in leaders eventually lead to abuse of position and privilege, religious communities must look out for leadership qualities such as Micah's own attractive, brilliant, and shinning self-assessment (3:8). They must in line with Moses' counsel insist on leaders, "who fear (יָרָא) God, men of truth

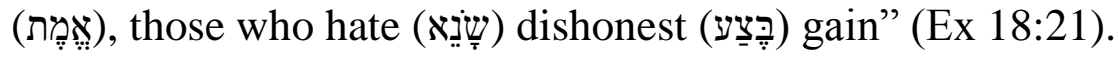

\section{Cautions against Economic Idolatry}

Prophets and priests in Ancient Israel and Judah were entrusted with the instruction of the people in matters of religion and ethics. Support for priestly ministry was organised under the Law (Deut 18:1-8), and prophets were occasionally rewarded in appreciation of their service (I Sam 9:7-8). However, to perform ministerial duties solely in the interest of financial or material gains results in mere professionalism or officialism and consequently religious commercialisation and profiteering. Micah's anguish indicates that privilege and money without a sense of responsibility always corrupt the competence to see clearly, and to preach and teach truth without lowering standard. ${ }^{65}$ If religious leaders occupy positions of integral function and responsibility only to give privileged and favoured treatment to those who bestow special and particular material benefits on them; disregard, take for granted the less privileged because of their social and economic standing; manipulate the word of God in their preaching, teaching and counselling ministry, it must be noted that such are a disgrace to God and they will ultimately be disgraced by God.

The attempt to lower the standard of God's demand on people through the religious functions of preaching, teaching and counselling has resulted in gathering, creating and maintaining faith communities that are peopled with strong, worldly, and materialistic consciousness. Today there is an extraordinary spectacle of religious programmes with large attendances of people; programmes designed explicitly to cater to fleshly desire, sensual appetites, and human pride. ${ }^{66}$ Contemporary popular religious passwords such as "sow a seed to proceed," "envelop to develop," "quality seed begets quality harvest," are used by religious leaders to invite people as merchants in exchange deals with God for some material benefits. It is regrettable to note that such strategy designed only to seek the fulfilment of fleshly desires has left massive economic idolatry in religious communities and weakened their evangelistic witness and transformation impact on society.

\footnotetext{
65 Smith-Christopher, Micah: A Commentary, 120.

66 John MacArthur, Ashamed of the Gospel: When the Church Becomes Like the World (Wheaton: Crossway Books, 1993), 17.
} 


\section{Religious Self-Deception and False Security}

The insidious strategy that Micah confronted was that of a perverted religion which alienated creed from lifestyle and guarantee grace and peace to transgressors so as to enable them to continue with transgression. Such religious ideology in Micah's perspective defines them as agents of social injustice. These religious hucksters, by their choosy and particular emphasis upon Zion and Yahwistic theology violated and frustrated the genuine intent of the covenant. This form of religious deception was the opium of an influential minority of oppressors that pacified their consciences to disregard their responsibility. It is impracticable, unrealistic and disastrous and must be condemned in its entire ramification. Accordingly, "Micah's task was the difficult one of attacking not irreligious immorality but the subtle combination of social injustice and a religion which virtually gave it its blessing."

The deficiency of moral integrity among these religious helmsmen of Micah's society is astonishing. Though they belong to a theocracy, they forgot its associated implications. The most incriminating aspect of their attitude is that they claimed to be relying on Yahweh, while they were obviously violating his laws and holding the people captive. According to Allen, "They saw no inconsistency between selfishly exploiting their wards and sanctimoniously expressing faith in the protective presence of their God. But such promises cannot exist in a moral vacuum." 68 They presumptuously demonstrated highlevel religious conviction but such that divorced religion from ethical value of honesty, responsibility and accountability. Truly, their outward religious formalism was devoid of inner religious beauty and reality; the fruits of the lives could not match their sacred commission. These religious leaders, having lost their sense of spiritual reality and responsibility $(3: 4,7)$, and filled with the spirit of self-sufficiency and self-confidence deceived the people into thinking that their artificial and perverted religious ideology and false sense of security would deliver them from justice and retribution. Micah observes the religious system with shoddy and morally corrupt resources as that which only encouraged materialism and social injustice, and which would ultimately prove useless. According to Micah, such cheer hypocrisy that stimulates vainglory will incur terrible responsibility $(3: 12)$.

Every establishment of faith in Yahweh without the willingness to appropriate Yahweh's word in covenant responsibility is nothing but superstition and pride and will most certainly erect a foundation for misguided impression, increased deception, distress, and suffering both at individual and national levels. This is probably a reflection of some religious communities and societies toady in which socio-economic contradictions and injustice have been validated by

67 Allen, "Micah's Social Concern," 26.
68 Allen, "Micah's Social Concern," 28. 
religion. Micah's indictment of Judah's charismatic and cultic leadership no doubt helps one to gain an informed perspective on how the essential relationship between prophetic and priestly religious responsibility and just ethical practices are indispensable to creating and sustaining a viable and healthy community where there is peace and stability.

\section{BIBLIOGRAPHY}

Achenbach, Reinhard. "A Prophet like Moses" (Deut 18:15) - "No Prophet like Moses" (Deut 34:10): Some Observations on the Relation between the Pentateuch and the Latter Prophets." Pages435-458 in The Pentateuch: International Perspectives on Current Research. Edited by T.B. Dozeman, K. Schmid and B.J. Schwartz; Tubingen: Mohr Seibeck, 2011.

Allen, Leslie C. "Micah's Social Concern.” Vox Evangelica 8 (1973): 22-32.

Andersen, Francis I and Freedman, David N. Micah: A New Translation with Introduction and Commentary. Anchor Bible 24E. New York: Doubleday, 2000.

Baker, Kenneth. The NIV Study Bible. Grand Rapids: Zondervan Publishing House, 1995. Rogers, Adrian. "False Prophets: Their Method, Manner and Motives." Available at http://www.oneplace.com/ministries/love-worth-finding/read/article s/false-prophets-theirmethod-manner-and-motive-14018.html (accessed $5^{\text {th }}$ July 2018).

Beentjes, Pancratius C. "Constructs of Prophets and Prophecy in the Book of Chronicles." Pages 21-40 in Constructs of Prophecy in the Former and Latter Prophets and Other Texts. Edited by Lester L. Grabbe \& Martti Nissinen. Atlanta: Society of Biblical Literature, 2011.

Block, Daniel I. "Empowered by the Spirit of God: The Holy Spirit in the Historiographic Writings of the Old Testament." Southern Baptist Journal of Theology 1/ 1 (1997): 41-52.

Bright, John. A History of Israel. Philadelphia: Westminster, 1981.

Carr, David M. An Introduction to the Old Testament: Sacred Texts and Imperial Contexts of the Hebrew Bible. Chichester: Blackwell Publishing, 2010.

The Formation of the Hebrew Bible: A New Reconstruction. Oxford: Oxford University Press, 2011.

Chaney, Marvin L. "The Political Economy of Peasant Poverty: What the EighthCentury Prophets Presumed but Did Not State. "Pages 34-60 in The Bible, the Economy, and the Poor. Edited by Ronald A. Simkins and Thomas M. Kelly. Journal of Religious Studies Supplement Series 10 (2014). URL: http://purl.org/JRS

Chang, Dongshin D. Phinehas, the Sons of Zadok, and Melchizedek: Priestly Covenant in Late Second Temple Texts. Library of Second Temple Studies 90. New York: Bloomsbury T \& T Clark, 2016.

De Jong, Matthijs J. "The Fallacy of 'True and False' in Prophecy Illustrated by Jer. 28:8-9." Journal of Hebrew Scripture 12/10 (2012): 1-31. https://doi.org /10.5508/jhs.2012.v12.a10

"Why Jeremiah is not among the Prophets: An Analysis of the Terms and נבאים in the Book of Jeremiah." Journal for the Study of Old Testament 35/4(2011): 483-510. https://doi.org/10.1177/0309089211402177 
Isaiah among the Ancient Near Eastern Prophets: A Comparative Study of the Earliest Stages of the Isaiah Tradition and the Neo-Assyrian Prophets. Vetus Testamentum Supplement 117. Leiden: Brill, 2007.

Dempster, Stephen G. Micah. The Two Horizons Old Testament Commentary. Grand Rapids, Michigan: William B. Eerdmans Publishing Company, 2017.

Driver, Samuel R. An Introduction to the Literature of the Old Testament. New York: Charles Scribner's Sons, 1913.

Edelman, Diana V. "From Prophets to Prophetic Books: The Fixing of the Divine Word." Pages 29-54 in The Production of Prophecy: Constructing Prophecy and Prophets in Yehud. Edited by Diana V. Edelman and Ehud Ben Zvi. London, Oakville: Equinox Publishing Ltd., 2009.

Gowan, Donald E. Theology of the Prophetic Books: The Death and Resurrection of Israel. Louisville: Westminster John Knox Press, 1998.

Grabbe, Lester L. Priests, Prophets, Diviners, Sages: A Socio-Historical Study of Religious Specialists in Ancient Israel. Valley Forge: Trinity Press International, 1995.

Groenewald, Alphonso. "Prophetic Witness in the Hebrew Bible: From Prophetic Word to Prophetic Books." Pages 29-46 in Prophetic Witness: An Appropriate Contemporary Mode of Public Discourse? Edited by Heinrich Bedford and Etienne de Villiers. Munster: LIT Verlag, 2011.

Hetrick, Lon. "Selling the Gospel: The Christian Hype that Stifles Christian Hope." Available at http://felixcheakam.com/77-selling-Jesus-at-a-discount.html (accessed 5th July 2018).

Hrobon, Bohdan. Ethical Dimension of the Cult in the Book of Isaiah. Beihefte zurZeitschrift für die Alttestamentliche Wissenschaft 418. Berlin/New York: De Gruyter, 2010.

Huber, Robert V., Grant Robert M. and Grant-Starter, Tracey. Who is Who in the Bible. Pleasantville; New York: Reader's Digest Association, Inc., 1994.

Huffmon, Herbert B. “A Company of Prophets: Mari, Assyria, Israel.” Pages 47-70 in Prophecy in its Ancient Near Eastern Context: Mesopotamian, Biblical, and Arabian Perspectives. Edited by M. Nissinen. Society of Biblical Literature, Semeia Studies 13. Atlanta, Society of Biblical Literature, 2000.

Jenson, Philip P. Obadiah, Jonah, Micah: A Theological Commentary. Library of Hebrew Bible/Old Testament Studies 496. New York: T \&T Clark, 2008.

Kaiser, Otto. Isaiah 1-12: A Commentary. London: SCM Press LTD, 1972.

Leuchter, Mark A. "The Priesthood in Ancient Israel." Biblical Theology Bulletin 40/2 (2010):100-110 (109). https://doi.org/10.1177/0146107910364344

Lindblom, Johannes. Prophecy in Ancient Israel. Oxford: Blackwell, 1962.

MacArthur, John. Ashamed of the Gospel: When the Church Becomes Like the World. Wheaton: Crossway Books, 1993.

Matthews, Victor H. Social World of the Hebrew Prophets. Peabody; Massachusetts: Hendrickson Publishers, Inc., 2001.

Mays, James L. Micah: A Commentary. London: SCM Press Ltd., 1976.

Mignon, Jacob. The Conceptual Coherence of the Book of Micah. Journal for the Study of Old Testament Supplement Series 322. Sheffield: Sheffield Academic Press, 2001.

Nogalski, James D. The Book of the Twelve: Micah-Malachi. Macon, Georgia: Smyth \& Helwys Publishing, 2011. 
O'Brien, Julia M. Micah. Wisdom Commentary 37. Collegeville, Minnesota: Michael Glazier Book, 2015.

Olyan, Saul M. "Ben Sira's Relationship to the Priesthood." Harvard Theological Review 80 (1987):261-286.

Premnath, Devadasan N. "Amos and Hosea: Socio-historical Background and Prophetic Critique." Word \& World 28/ 2 (2008): 125-132

Preuss, Horst D. Old Testament Theology. Louisville: Westminster John Knox, 1996.

Provan, Iain, Long V. Philips and Longman Tremper III. A Biblical History of Israel. Louisville: Westminster John Knox Press, 2003.

Redditt, Paul L. Introduction to the Prophets. Grand Rapids, Michigan: William B. Eerdmans Publishing Company, 2008.

Rendtorff, Rolf. The Canonical Hebrew Bible: A Theology of the Old Testament. Translated by David E. Orton. Tools for Biblical Study, 7. Leiden: Deo Publishing, 2005.

Routledge, Robin L. Old Testament Theology: A Thematic Approach. Apollos: InterVarsity Press, 2008.

Schofield, Alison and Vanderkam, James C. "Were the Hasmoneans Zadokites?" Journal of Biblical Literature 124 (2005):73-87. https://doi.org/10.2307 B30040991

Shalom-Guy, Hava. "The Call Narratives of Gideon and Moses: Literary Convention or More?" Journal of Hebrew Scripture 11/11 (2011): 2-19. https://doi.org/ 10.5508/jhs.2011.v11.a11

Smith, Ralph L. Micah-Malachi. Word Biblical Commentary 32. Waco: World Books, 1984.

Smith-Christopher, Daniel L. Micah: A Commentary. The Old Testament Library. Louisville, Kentucky: Westminster John Knox Press, 2015.

Tiemeyer, Lena-Sofia. Priestly Rites and Prophetic Rage: Post-exilic Prophetic Critique of the Priesthood. Forschungen zum Alten Testament 2/19. Tubingen: Mohr Siebeck, 2006.

Van der Toorn, Karel. Scribal Culture and the Making of the Hebrew Bible. London: Harvard University Press, 2007.

Von Rad, Gerhard. Old Testament Theology. London: Oliver \& Boyd 1962.

Waltke, Bruce K. A Commentary on Micah. Grand Rapids: Eerdmans, 2007. "Micah." Pages 591-764 in The Minor Prophets: An Exegetical and Expository Commentary. Edited by T. E. McComiskey. Grand Rapids Mich.: Baker, 1993.

Wolff, Hans W. Micah: A Commentary. Translated by Gary Stansell. Minneapolis: Augsburg Fortress, 1990.

Blessing Onoriode Boloje is a lecturer at the Baptist Theological Seminary, EkuNigeria, Research Fellow of the Alexander von Humboldt Foundation, RuhrUniversität Bochum, Germany and Research Associate, Department of Old Testament Studies, Faculty of Theology, University of Pretoria, 0002, Pretoria, South Africa. Email: pstbobson@yahoo.co.uk ORCID ID: https://orcid.org/ 0000-0002-7480-3805 